\title{
The Frequency of the Clinical Risk Factors in Postmenopausal Osteoporosis
}

\author{
Postmenopozal Osteoporozda Klinik Risk Faktörlerinin Sıklı̆̆
}

\author{
Yeşim Gökçe KUTSAL, ${ }^{1}$ Serpil SAVAŞ, ${ }^{2}$ Fatma INANICI, ${ }^{1}$ Oya ÖZDEMİR, ${ }^{3}$ Sevilay KARAHAN, ${ }^{4}$ Asuman DOĞAN, ${ }^{5}$ \\ Sami HİZMETLİ, ${ }^{6}$ Ayhan KAMANLI, ${ }^{7}$ Banu KURAN, ${ }^{8}$ Sema ÖNCEL, ${ }^{9}$ Selda SARIKAYA, ${ }^{10}$ \\ Kazım ŞENEL, ${ }^{11}$ Hatice UĞURLU, ${ }^{12}$ Pelin YAZGAN ${ }^{13}$ \\ ${ }^{1}$ Department of Physical Medicine and Rehabilitation, Medical Faculty of Hacettepe University, Ankara, Turkey \\ ${ }^{2}$ Department of Physical Medicine and Rehabilitation, Medical Faculty of Süleyman Demirel University, Isparta, Turkey \\ ${ }^{3}$ Department of Physical Medicine and Rehabilitation, Hacettepe University Kastamonu Medical School, Ankara, Turkey \\ ${ }^{4}$ Department of Biostatistics, Medical Faculty of Hacettepe University, Ankara, Turkey \\ ${ }^{5}$ Department of $5^{\text {th }}$ Physical Medicine and Rehabilitation, Ankara Physical Medicine and Rehabilitation Training and Research Hospital, Ankara, Turkey \\ ${ }^{6}$ Department of Physical Medicine and Rehabilitation, Medical Faculty of Cumhuriyet University, Sivas, Turkey

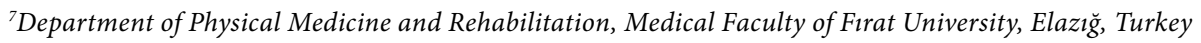 \\ ${ }^{8}$ Department of Physical Medicine and Rehabilitation, Şişli Etfal Training and Research Hospital, İstanbul, Turkey \\ ${ }^{9}$ Department of Physical Medicine and Rehabilitation, Medical Faculty of Dokuz Eylül University, Izmir, Turkey \\ ${ }^{10}$ Department of Physical Medicine and Rehabilitation, Medical Faculty of Karaelmas University, Zonguldak, Turkey \\ ${ }^{11}$ Department of Physical Medicine and Rehabilitation, Medical Faculty of Atatürk University, Erzurum, Turkey \\ ${ }^{12}$ Department of Physical Medicine and Rehabilitation, Medical Faculty of Selçuk University, Konya, Turkey \\ ${ }^{13}$ Department of Physical Medicine and Rehabilitation, Medical Faculty of Harran University, Şanluurfa, Turkey
}

Objectives: This study aims to identify the frequency of clinical risk factors associated with osteoporosis in postmenopausal women.

Patients and methods: In this cross-sectional, observational, multicenter study, a total of 730 postmenopausal women were assessed for risk factors associated with osteoporosis. The assessment included a standardized questionnaire which recorded the following clinical risk factors: family and personal histories of fractures, prolonged immobilization, sun exposure, lifelong sedentary lifestyle, smoking history, low calcium intake in childhood and adulthood, excessive caffeine intake, high sodium intake, inadequate protein intake, number of pregnancies, age at menopause, the presence of premature menopause, primary and secondary amenorrhea, medical conditions, and chronic use of prescription drugs.

Results: The most frequent clinical risk factors for osteoporosis were inadequate sun exposure (53.3\%), current sedentary lifestyle $(52.9 \%)$, low calcium intake in adulthood (45.1\%) and childhood (41.9\%), and sedentary lifestyle in adolescence (27.9\%). A total of 707 patients (96.5\%) described more than one risk factor, while $74.3 \%$ of the patients reported one clinical risk factor at least for secondary osteoporosis.

Conclusion: Adequate sun exposure and proper intake of dietary calcium beginning in childhood combined with lifelong daily physical activity may play a role in preventing osteoporosis in postmenopausal women. In addition, physicians should be aware of the high probability of secondary osteoporosis in this patient group.

Key words: Osteoporosis; postmenopausal; risk factor.

\begin{abstract}
Amaç: Bu çalışmada postmenopozal kadınlarda osteoporoz ile ilişkilendirilen klinik risk faktörlerinin sıklığı belirlendi.

Hastalar ve yöntemler: Bu kesitsel, gözlemsel, çokmerkezli çalışmada toplam 730 postmenopozal kadın osteoporozun klinik risk faktörleri açısından değerlendirildi. Değerlendirmede şu klinik risk faktörlerinin kaydedildiği standart bir sorgulama formu kullanıldı: ailesel ve kişisel kırık öyküsü, uzamış hareketsizlik, güneş maruziyeti, yaşam boyu hareketsiz yaşam biçimi, sigara kullanımı, çocukluk ve erişkinlik döneminde düşük kalsiyum alımı, aşırı kafein alımı, yüksek sodyum alımı, yetersiz protein alımı, gebelik sayısı, menopoz yaşı, prematür menopoz varlığı, primer ve sekonder amenore, tıbbi hastalıklar ve kronik reçeteli ilaç kullanımı.

Bulgular: Osteoporoz açısından en sık rastlanan klinik risk faktörleri, yetersiz güneş maruziyeti (\%53.3), mevcut hareketsiz yaşam biçimi (\%52.9), erişkin (\%45.1) ve çocukluk çağında (\%41.9) düşük kalsiyum alımı ve ergenlik döneminde hareketsiz yaşam biçimi (\%27.9) idi. Toplam 707 hasta (\%96.5) birden fazla klinik risk faktörü tanımlarken, hastaların \%74.3'ü sekonder osteoporoz açısından en az bir klinik risk faktörü bildirdi. Sonuç: Yeterli güneş maruziyeti, çocukluktan itibaren beslenmede yeterli kalsiyum alımı ve hareketli bir yaşam biçimi, postmenopozal kadınların osteoporozdan korunmasında rol oynayabilir. Buna ilave olarak, hekimler bu hasta grubundaki yüksek sekonder osteoporoz olasılığının farkında olmalıdırlar.

Anahtar sözcükler: Osteoporoz; postmenopozal; risk faktörü.
\end{abstract}

\section{Received: January 17, 2013 Accepted: May 08, 2013}

Correspondence: Serpil Savaş, M.D. Süleyman Demirel Üniversitesi Tıp Fakültesi Fiziksel Tıp ve Rehabilitasyon Anabilim Dalı, 32260 Çünür, Isparta, Turkey.

Tel: +90 533 - 3911628 e-mail: serpilsavas@yahoo.com

C2013 Turkish League Against Rheumatism. All rights reserved. 
Osteoporosis is defined as a skeletal disorder characterized by compromised bone strength leading to an increased risk of fracture. ${ }^{[1]}$ To properly diagnosis this disease, bone mineral density (BMD) is measured, and this is generally considered to be a key element for identifying high-risk subjects who can benefit the most from preventive bone active treatment to avoid fractures. ${ }^{[2,3]}$ However, osteoporosis is no longer considered to be solely a disorder related to low $\mathrm{BMD}$, and BMD alone cannot sufficiently explain the different fracture rates. For example, although Turks have one of the lowest fracture rates in Europe, the BMD values in this country were low compared with Swedes. ${ }^{[4,5]}$ This leads to the conclusion that for a given BMD level, the risk of fracture varies with age and the presence of other risk factors. ${ }^{[6]}$ In addition, the combination of clinical risk factors and BMD provide higher specifity and sensitivity than either of these provides individually. ${ }^{[7]}$

Several international epidemiological surveys in different parts of the world have extensively analyzed the potential risk factors for osteoporosis and identified the following: age, smoking history, excessive alcohol consumption, low body mass index (BMI), low dietary calcium intake, vitamin D deficiency, little or no physical activity, visual impairment, frequent falls, female gender, premature menopause, amenorrhea, previous fragility fracture, a family history of hip fracture, low BMD, high bone turnover, neuromuscular disorders, longterm glucocorticoid therapy, and rheumatoid arthritis (RA). ${ }^{[2,7-14]}$ In addition, being Asian or Caucasion was also determined to be a potential risk factor. The conclusions obtained from these studies are controversial and vary according to ethnic groups. In Turkish postmenopausal women, the validated clinical risk factors were the following: being over the age of 50 or at the age of menopause along with BMI, height, duration of menopause, illiteracy, parity, anemia, sun exposure, including sunbathing and daily outdoor activities, a sedentary lifestyle, a history of fracture, duration of breastfeeding, dietary calcium intake, smoking history, tea and caffein intake, and the presence of chronic disease, chronic kidney disease, or type 2 diabetes. ${ }^{[15-24]}$

The use of clinical risk factors to identify patients at risk for osteoporosis and fracture has the potential to allow for the modification of living habits. In addition, identifying patients at risk by utilizing a number of algorithms associated with clinical risk factors may assist physicians in selecting patients for BMD testing. ${ }^{[25,26]}$ The clear advantages of using such risk factors are the low cost and easy execution, especially in developing countries where healthcare resources are scarce. ${ }^{[27]}$ Risk factors that are inherent to each country must be identified before making a clinical decision because the risk factors vary from society to society. ${ }^{[21]}$ For example, excessive alcohol intake is a risk factor in Western countries, but it is of little concern in Turkey where the vast majority do not drink alcohol because of their religious beliefs. ${ }^{[28]}$

The aim of this study was to describe the most frequently reported clinical risk factors in postmenopausal women with osteoporosis who are living in different geographical locations in Turkey.

\section{PATIENTS AND METHODS}

This observational, cross-sectional study was conducted at 10 university hospitals (Ankara, Sivas, Konya, Elazığ, Şanlıurfa, İstanbul, Zonguldak, Erzurum, Isparta, and İzmir) located in seven different geographical areas in Turkey (Marmara, Black Sea, Eastern Anatolia, Southeast Anatolia, Mediterranean, Aegean, and Central Anatolia) between November 2010 and November 2011. A total of 730 postmenopausal women (mean age $64.72 \pm 9.79$ years; range $40-90$ years) were included in the study. Each of the women were at least 12 months postmenopausal and $\geq 45$ years old or had undergone a bilateral oophorectomy at $\geq 40$ years of age). Osteoporosis was diagnosed according to the World Health Organization (WHO) criteria, ${ }^{[29,30]}$ which defines it as having a spinal or hip BMD of 2.5 standard deviations or more below the mean for healthy, young women (T-score of -2.5 or below). These measurements were calculated using dualenergy X-ray absorptiometry (DXA) on the lumbar spine (L1-L4) and femoral neck via a Norland XR-46 bone densitomer with dynamic filtration (Norland Corp, Fort Atkinson, WI, USA), a Hologic QDR4500A bone densitometer (Hologic, Inc. Bedford, MA, USA), or a GE Lunar DPX Pro densitometer (GE Healthcare, Little Chalfont, UK). Afterwards, the patients completed a standardized questionnaire which provided information on their demographic, reproductive, and lifestyle characteristics, family and personal history of osteoporosis and fragility fractures, intake of medicine, and the presence of comorbid diseases causing secondary osteoporosis.

The demographic variables included age, height, and weight along with the BMI, which was calculated using the weight $(\mathrm{kg}) /$ height $\left(\mathrm{m}^{2}\right)$ formula. 
The reproductive factors were age and type of menopause [premature ( $<40$ years of age), natural, or surgical], number of live births, and primary or secondary amenorrhea (>one year).

The lifestyle characteristics were composed of smoking history (active or passive smoking), current low calcium intake $(<1000 \mathrm{mg} /$ day $)$, low dietary calcium intake in childhood $(<500-850 \mathrm{mg} /$ day), excessive alcohol use ( $\geq$ three drinks/day), excessive caffeine use ( $>$ four cups/day), high sodium intake ( $>2 \mathrm{gr} /$ day), inadequate protein intake, prolonged immobilization (>two-three months), sun exposure (daily outdoor activity), a current sedentary lifestyle, and a sedentary lifestyle in adolescance. Participants were categorised as "veiled" or "not veiled" depending on whether they had been covered except for the hands and face and worn a headscarf for the majority of time from after puberty until menopause.

In addition, the questions concerning family and personal history of osteoporosis and fragility fractures included information related to a family history of osteoporosis as diagnosed by a physician, a family history of low trauma fracture after the age of 50 or kyphosis, a family history of hip fracture (maternal, paternal, sister), and a personal history of fracture after the age of 40 . If they answered the last question in the affirmative, the type of the fracture was noted as occurring in the vertebra, wrist, hip, or other location).

The patients were also asked about their use of systemic glucocorticoids ( $>5 \mathrm{mg} /$ day prednisone for more than three months), antideprassants, heparin, anticonvulsants, and aluminum-containing antacids in the questionnaire.

The medical conditions were assessed via questions regarding the presence of rheumatoid arthritis (RA), primary hyperthyroidism, celiac disease, inflammatory bowel disease, multiple myeloma, weight loss (10\% of weight at age 25 ), anorexia nervosa or other eating disorders, ankylosing spondylitis, hyperthyroidism, malabsorption syndromes, chronic liver disease, organ transplantation, malignancies, hypogonadism, renal disease, and neuromuscular disorders such as multiple sclerosis (MS), Parkinson's disease, and hemiplegia, and spinal cord injuries). Each patient was also asked about previous gastrointestinal surgery.

High-performance liquid chromatography (HPLC) was used to determine the presence of 25-hydroxyvitamin D3 [25(OH)D] in the plasma, and a precipitation step combined with extraction was performed before the HPLC analysis. A reversed phase column and chromatograms were identified via an ultraviolet (UV) detector. The normal ranges were $20-150 \mathrm{mg} / \mathrm{dL}$ for summer and 8-60 mg/dL for winter.

Informed consent for this study was obtained from all of the participants, and it was approved by the Hacettepe University Senate Ethics Committee.

\section{Statistical analysis}

Statistical analyses were carried out with the SPSS for Windows version 15.0 statistical software (SPSS Inc., Chicago, IL, USA). Continuous variables were presented as mean \pm standard deviation and range (min.-max.), and categorical variables were summarized as frequencies and percentages. The distributions of the numeric variables were examined using the Kolmogorov-Smirnov test for normality, and differences between the groups were determined via an independent samples t-test or the MannWhitney $U$ test. In addition, the association between the continuous variables was examined using the Pearson correlation coefficient.

\section{RESULTS}

The mean BMI was $27.73 \pm 4.91 \mathrm{~kg} / \mathrm{m}^{2}$ (range 14.8651.02 ), and the mean age at menopause was $45.85 \pm 5.93$ years (range 27-68). We also determined that the mean duration of menopause was $19.47 \pm 10.21$ years (range 1-52), and the mean number of pregnancies was 4.69 \pm 2.86 (range 0-15). Five hundred and seventy-three patients (78.5\%) had natural menopause while 147 patients (20.1\%) had surgical menopause. Furthermore, 160 patients (21.9\%) had a history of fragility fracture (22 hip fractures, 68 vertebra fractures, 25 elbow fractures, one vertebra fracture, and one elbow fracture).

Insufficient sun exposure was reported by 389 patients (53.3\%) while 386 (52.9\%) stated that their current lifestyle was sedentary and 204 (27.9\%) said they had a sedentary lifestyle during adolescence. Three hundred and twenty-nine patients (45.1\%) answered that their current dietary calcium intake was low while 306 patients $(41.9 \%)$ had a history of low calcium intake in childhood. Furthermore, 185 patients $(25.3 \%)$ had a family history of osteoporosis, $161(22.1 \%)$ had a personal history of fragility fracture after the age of 40, 98 (13.4\%) had a family history of low trauma fracture, and 154 (21.1\%) reported a high sodium intake. Additionally, 141 patients (19.3\%) 
were passive smokers, and $47(6.4 \%)$ were active smokers. Moreover, 134 patients $(18.4 \%)$ had a history of prolonged immobilization, $125(18.6 \%)$ reported an inadequate protein intake, 85 (11.6\%) had premature menopause, $64(8.8 \%)$ had a family history of hip fracture, and $55(7.5 \%)$ had a history of primary or secondary amenorrhea. We also found that 35 patients $(4.8 \%)$ answered that they consumed too much caffeine, and one patient (0.1\%) reported excessive alcohol intake.

Regarding the chronic use of medications, 83 patients (11.4\%) had used systemic glucocorticoids while the same number responded that they had used antidepressants. We also noted that 48 patients (6.6\%) stated that they had used aluminum-containing antiacids, 23 (3.2\%) had taken heparin, and 11 (1.5\%) had taken anticonvulsants.

Furthermore, the following informations was obtained related to the patients' medical conditions: 50 patients $(6.8 \%)$ had hyperthyroidism, 42 (5.8\%) had undergone previous gastrointestinal surgery, 39 (5.3\%) suffered from RA, 39 (5.3\%) reported neuromuscular disorders, 28 (3.8\%) had renal disease, 22 (3\%) had malignancies, 20 (2.7\%) suffered from chronic liver disease, 13 patients (1.8\%) reported weight loss, 11 (1.5\%) had hypogonadism, 10 (1.4\%) had primary hyperparathyroidism, seven reported a diagnosis of AS, four (0.5\%) had celiac disease, two $(0.3 \%)$ suffered from multiple myeloma, two (0.3\%) had malabsorption syndromes, one $(0.1 \%)$ had inflammatory bowel disease, and one patient $(0.1 \%)$ had undergone an organ transplant. In addition, 707 patients (96.5\%) described more than one risk factor.

The mean 25(OH)D level was $22.77 \pm 23.29 \mathrm{mg} / \mathrm{dL}$ (0-134 mg/dL). We also noted that 399 patients (54.7\%) were "veiled", and that being "veiled" was negatively associated with reported sun exposure $(r=-0.085$, $\mathrm{p}<0.05)$. Additionally, the 25(OH)D levels were significantly lower in the "veiled" patients compared with the "non-veiled" patients $(18.04 \pm 20.06 \mathrm{mg} / \mathrm{dL}$ vs. $29.93 \pm 27.48 \mathrm{mg} / \mathrm{dL}$, respectively; $\mathrm{p}<0.0001)$.

\section{DISCUSSION}

To our knowledge, this is the first study that has investigated the frequency of osteoporotic risk factors in such a large sample of postmenopausal women with osteoporosis in Turkey. According to our results, the most frequently reported risk factors for this disease were inadequate sun exposure, low calcium intake since childhood, and a lifelong sedentary lifestyle.
Half of the patients answered that they had insufficient sun exposure, and this was negatively correlated with the $25(\mathrm{OH}) \mathrm{D}$ values. Our patients who were veiled reported more insufficient sun exposure and they were found to have lower vitamin $\mathrm{D}$ values than non-veiled patients. Most people (90-100\%) get their vitamin $\mathrm{D}$ from exposure to sunlight ${ }^{[31]}$ because only a few foods, including, oily fish such as salmon, mackarel, and herring along with fish oil (e.g., cod liver oil), contain vitamin $\mathrm{D}^{[32]}$ This vitamin is not only important for bone mineralization but also for optimal muscle function and balance. Sunlight is the cheapest and easiest source of vitamin D in Turkey. Therefore, physicians must encourage postmenopausal women to undertake more outdoor activities in order to have more direct exposure to the sun since this could prevent osteoporosis. Exposing the hands, face, arms, and legs to sunlight for an amount of time equal to approximately $25 \%$ of what it takes to develop a mild sunburn [i.e., one minimal erythemal dose (MED) two to three times a week] is enough to satisfy the vitamin $\mathrm{D}$ requirement and store some of this vitamin in the body fat. ${ }^{[31]}$

Physical inactivity is a major health problem worldwide, with one of every five adults being categorized as physically inactive. ${ }^{[33]}$ Our findings support this since half of our patients reported a physically inactive lifestyle. Weight-bearing exercise is associated with a small but significant increase in BMD in men and women. ${ }^{[34]}$ In addition, among patients with osteoporosis, exercise is associated with a decreased risk of hip fractures. Furthermore, exercise may also improve muscle tone and reduce the risk of falls. A minimum of 30 minutes of physical activity (such as brisk walking) on most, if not all, days of the week is advised for the prevention of

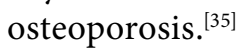

Most of our postmenopausal patients with osteoporosis (74\%) reported a secondary osteoporosis cause. Secondary osteoporosis is defined as bone loss, microarchitectural alterations, and fragility fractures due to an underlying disease or concurrent medication. ${ }^{[36]}$ The response to osteoporosis therapy may be limited if the underlying disorder goes unrecognized and if other risk factors are present. Treatment of the underlying disease is pivotal. All patients with secondary osteoporosis should receive adequate calcium and vitamin $\mathrm{D}$ supplements and should maintain normal calcium and parathyroid hormone (PTH) serum levels along with 25(OH)D serum concentrations of at least $30 \mathrm{ng} / \mathrm{ml} .^{[37]}$ 
In this study, one of the most frequently reported clinical risk factors was low daily dietary calcium intake in adulthood. Calcium, like vitamin $\mathrm{D}$, is necessary for normal skeletal homeostasis. The Recommended Dietary Allowance (RDA) of elemental calcium for postmenopausal women is $1200 \mathrm{mg}{ }^{[38]}$ Most of our patients also reported low calcium intake in childhood. Nutritional needs during adolescence are influenced by the onset of puberty, with its associated increased growth rate and changes in body compositions. From the preadolescent years to the end of the second decade of life, bone size and bone mass increase rapidly. The accumulation of total BMD between the ages of eight and 18 is approximately 146 grams per year, with the greatest deposition occurring during puberty. ${ }^{[39]}$ Adequate calcium intake is necessary to maximize peak bone mass and minimize both the risk of fractures in adolescence and the development of osteoporosis in adulthood. ${ }^{[40]}$ The recommended calcium intake in children between the ages of three and eight is $800 \mathrm{mg} / \mathrm{day}$, while it is $1300 \mathrm{mg} / \mathrm{d}$ for older children and adolescents between the ages of 9 and 17. ${ }^{[41]}$ The Turkish population must be informed about the importance of adequate lifelong calcium intake for bone health.

Bone mineral density and clinical risk factors predict hip and other osteoporotic fractures. The combination of these two items provides higher specifity and sensitivity than either of them can supply individually. ${ }^{[7]}$ The clinical risk factors must be validated in order to be combined with BMD. For example, in our study we found that some risk factors, such as inadequate protein intake ${ }^{[42]}$ and high sodium intake, ${ }^{[43]}$ occur quite frequently in Turkish postmenopausal patients, but these risk factors remain unvalidated for our population. In addition, heavy alcohol intake in postmenopausal women is an extremely rare occurrence in our population. For example, in the study by Aydin ${ }^{[28]}$ among 1,106 Turkish women, 1,059 (91.5\%) women said they had never consumed alcohol. However, in the Fracture Risk Assessment Tool (FRAX ${ }^{\circledR}$ ), one of the main risk factors that is evaluated is alcohol intake. ${ }^{[4]}$ Hence, a country-specific model utilizing the most important risk factors for osteoporosis in Turkish patients should be developed. Most of the previous studies in Turkey that sought to determine the clinical risk factors for this disease involved small sample sizes and a limited number of potential determinants. We believe that further studies are urgently needed which can correlate the clinical osteoporotic risk factors, including the use of prescription drugs and medical conditions, with the BMD values. Another limitation of our study was that the data for the risk factors was based on the patients' self-reports.

\section{Conclusion}

In this study, we determined that adequate sun exposure and dietary calcium intake since childhood in combination with a lifelong habit of daily physical activity may play a role in preventing osteoporosis in postmenopausal women. We also believe that more attention should be paid to the causes of secondary osteoporosis in the Turkish population.

\section{Declaration of conflicting interests}

The authors declared no conflicts of interest with respect to the authorship and/or publication of this article.

\section{Funding}

The authors received no financial support for the research and/or authorship of this article.

\section{REFERENCES}

1. Osteoporosis prevention, diagnosis, and therapy. NIH Consens Statement. 2000;17:1-45.

2. Unnanuntana A, Gladnick BP, Donnelly E, Lane JM. The assessment of fracture risk. J Bone Joint Surg [Am] 2010;92:743-53.

3. Johnell O, Kanis JA, Oden A, Johansson H, De Laet C, Delmas $\mathrm{P}$, et al. Predictive value of BMD for hip and other fractures. J Bone Miner Res 2005;20:1185-94.

4. Tuzun S, Akarirmak U, Uludağ M, Tuzun F, Kullenberg R. Is BMD sufficient to explain different fracture rates in Sweden and Turkey? J Clin Densitom 2007;10:285-8.

5. Tuzun S, Eskiyurt N, Akarirmak U, Saridogan M, Senocak $\mathrm{M}$, Johansson $\mathrm{H}$, et al. Incidence of hip fracture and prevalence of osteoporosis in Turkey: the FRACTURK study. Osteoporos Int 2012;23:949-55.

6. Dargent-Molina P. Epidemiology and risk factors for osteoporosis. Rev Med Interne. 2004;25 Suppl 5:S517-25. [Abstract]

7. Kanis JA, Oden A, Johnell O, Johansson H, De Laet C, Brown J, et al. The use of clinical risk factors enhances the performance of BMD in the prediction of hip and osteoporotic fractures in men and women. Osteoporos Int 2007;18:1033-46.

8. Aggarwal N, Raveendran A, Khandelwal N, Sen RK, Thakur JS, Dhaliwal LK, et al. Prevalence and related risk factors of osteoporosis in peri- and postmenopausal Indian women. J Midlife Health 2011;2:81-5.

9. Malhotra N, Mithal A. Osteoporosis in Indians. Indian J Med Res 2008;127:263-8. 
10. Nahas EA, Kawakami MS, Nahas-Neto J, Buttros Dde A, Cangussu L, Rodrigues AB. Assessment of risk factors for low bone mineral density in Brazilian postmenopausal women. Climacteric 2011;14:220-7.

11. Hannan MT, Felson DT, Dawson-Hughes B, Tucker KL, Cupples LA, Wilson PW, et al. Risk factors for longitudinal bone loss in elderly men and women: the Framingham Osteoporosis Study. J Bone Miner Res 2000;15:710-20.

12. Blotman F, Cortet B, Hilliquin P, Avouac B, Allaert FA, Pouchain D, et al. Characterisation of patients with postmenopausal osteoporosis in French primary healthcare. Drugs Aging 2007;24:603-14.

13. Shilbayeh S. Prevalence of osteoporosis and its reproductive risk factors among Jordanian women: a cross-sectional study. Osteoporos Int 2003;14:929-40.

14. Pinheiro MM, Ciconelli RM, Martini LA, Ferraz MB. Clinical risk factors for osteoporotic fractures in Brazilian women and men: the Brazilian Osteoporosis Study (BRAZOS). Osteoporos Int 2009;20:399-408.

15. Akkus Z, Camdeviren H, Celik F, Gur A, Nas K. Determination of osteoporosis risk factors using a multiple logistic regression model in postmenopausal Turkish women. Saudi Med J 2005;26:1351-9.

16. Demir B, Haberal A, Geyik P, Baskan B, Ozturkoglu E, Karacay $\mathrm{O}$, et al. Identification of the risk factors for osteoporosis among postmenopausal women. Maturitas 2008;60:253-6.

17. Akdeniz N, Akpolat V, Kale A, Erdemoglu M, Kuyumcuoglu U, Celik Y. Risk factors for postmenopausal osteoporosis: anthropometric measurements, age, age at menopause and the time elapsed after menopause onset. Gynecol Endocrinol 2009;25:125-9.

18. Yazici S, Korkmaz U, Erkan M, Korkmaz N, Erdem Baki A, Alçelik A, et al. The effect of breast-feeding duration on bone mineral density in postmenopausal Turkish women: a population-based study. Arch Med Sci 2011;7:486-92.

19. Korkmaz U, Korkmaz N, Yazici S, Erkan M, Baki AE, Yazici $M$, et al. Anemia as a risk factor for low bone mineral density in postmenopausal Turkish women. Eur J Intern Med 2012;23:154-8.

20. Kayalar G, Cevikol A, Yavuzer G, Sanisoglu Y, Cakci A, Arasil T. The value of calcaneal bone mass measurement using a dual X-ray laser Calscan device in risk screening for osteoporosis. Clinics (Sao Paulo) 2009;64:757-62.

21. Dursun N, Akin S, Dursun E, Sade I, Korkusuz F. Influence of duration of total breast-feeding on bone mineral density in a Turkish population: does the priority of risk factors differ from society to society? Osteoporos Int 2006;17:651-5.

22. Sahin G, Bağis S, Cimen OB, Ozişik S, Güler H, Erdoğan C. Lumbar and femoral bone mineral density in type 2 Turkish diabetic patients. Acta Medica (Hradec Kralove) 2001;44:141-3.
23. Hamdi Kara I, Aydin S, Gemalmaz A, Aktürk Z, Yaman $\mathrm{H}$, Bozdemir $\mathrm{N}$, et al. Habitual tea drinking and bone mineral density in postmenopausal Turkish women: investigation of prevalence of postmenopausal osteoporosis in Turkey (IPPOT Study). Int J Vitam Nutr Res 2007;77:389-97.

24. Gemalmaz A, Discigil G, Sensoy N, Basak O. Identifying osteoporosis in a primary care setting with quantitative ultrasound: relationship to anthropometric and lifestyle factors. J Bone Miner Metab 2007;25:184-92.

25. İpek A, Gafuroğlu Ü, Bodur H, Yılmaz Ö. Osteoporosis risk assessment. Turk J Phys Med Rehab 2012;58:212-9.

26. Salaffi F, Silveri F, Stancati A, Grassi W. Development and validation of the osteoporosis prescreening risk assessment (OPERA) tool to facilitate identification of women likely to have low bone density. Clin Rheumatol 2005;24:203-11.

27. Pinheiro Mde M, Eis SR. Epidemiology of osteoporotic fractures in Brazil: what we have and what we need. Arq Bras Endocrinol Metabol 2010;54:164-70.

28. Aydin ZD. Determinants of age at natural menopause in the Isparta Menopause and Health Study: premenopausal body mass index gain rate and episodic weight loss. Menopause 2010;17:494-505.

29. Assessment of fracture risk and its application to screening for postmenopausal osteoporosis. Report of a WHO Study Group. World Health Organ Tech Rep Ser 1994;843:1-129.

30. Kanis JA, Melton LJ 3rd, Christiansen C, Johnston CC, Khaltaev N. The diagnosis of osteoporosis. J Bone Miner Res 1994;9:1137-41.

31. Holick MF. Vitamin D: A millenium perspective. J Cell Biochem 2003;88:296-307.

32. Holick MF, Chen TC. Vitamin D deficiency: a worldwide problem with health consequences. Am J Clin Nutr 2008;87:1080S-6S.

33. Dumith SC, Hallal PC, Reis RS, Kohl HW 3rd. Worldwide prevalence of physical inactivity and its association with human development index in 76 countries. Prev Med 2011;53:24-8.

34. Wolff I, van Croonenborg JJ, Kemper HC, Kostense PJ, Twisk JW. The effect of exercise training programs on bone mass: a meta-analysis of published controlled trials in preand postmenopausal women. Osteoporos Int 1999;9:1-12.

35. U.S. Department of Health and Human Services. Physical Activity and Health: A Report of the Surgeon General. Atlanta, GA: U.S. Department of Health and Human Services Centers for Disease Control and Prevention, National Center for Chronic Disease Prevention and Health Promotion; 1996. p. 130-2. Available from: http:// profiles.nlm.nih.gov/ps/access/NNBBHC.pdf. [Access date: December 27, 2012]

36. Painter SE, Kleerekoper M, Camacho PM. Secondary osteoporosis: a review of the recent evidence. Endocr Pract 2006;12:436-45.

37. Hofbauer LC, Hamann C, Ebeling PR. Approach to the patient with secondary osteoporosis. Eur J Endocrinol 2010;162:1009-20. 
38. Institute of Medicine. Report at a Glance, Report Brief: Dietary Reference Intakes for Calcium and Vitamin D, released 11/30/2010. Available from: http://www. iom.edu/Reports/2010/Dietary-Reference-Intakes-forCalcium-and-Vitamin-D/Report-Brief.aspx. [Access date: December 01, 2010].

39. Matkovic V, Jelic T, Wardlaw GM, Ilich JZ, Goel PK, Wright JK, et al. Timing of peak bone mass in Caucasian females and its implication for the prevention of osteoporosis. Inference from a cross-sectional model. J Clin Invest 1994;93:799-808.

40. Sandler RB, Slemenda CW, LaPorte RE, Cauley JA, Schramm MM, Barresi ML, et al. Postmenopausal bone density and milk consumption in childhood and adolescence. Am J Clin Nutr 1985;42:270-4.
41. NIH Consensus Development Panel on Osteoporosis Prevention, Diagnosis, and Therapy. Osteoporosis prevention, diagnosis, and therapy. JAMA 2001;285:785-95.

42. Bonjour JP. Protein intake and bone health. Int J Vitam Nutr Res 2011;81:134-42.

43. Woo J, Kwok T, Leung J, Tang N. Dietary intake, blood pressure and osteoporosis. J Hum Hypertens 2009;23:451-5.

44. Kanis JA on behalf of the World Health Organization Scientific Group. Assessment of osteoporosis at the primary health-care level. Technical Report. WHO Collaborating Centre, University of Shefffield, UK; 2008. Available from: http://www.shef.ac.uk/FRAX. [Access date: October 15, 2012]. 